\title{
Estimating zonal Ekman transport along coastal Senegal during passage of Hurricane Fred, 30-31 August 2015
}

\author{
Abdou Lahat Dieng $^{1}$ (D) Siny Ndoye ${ }^{1,2} \cdot$ Gregory S. Jenkins $^{3} \cdot$ Saïdou M. Sall ${ }^{1} \cdot$ Amadou T. Gaye $^{1}$
}

Received: 5 October 2020 / Accepted: 15 April 2021

Published online: 29 April 2021

(c) The Author(s) 2021

OPEN

\begin{abstract}
We examine the role of zonal Ekman transport along the coast of Senegal on 30 August 2015 when the tropical disturbance associated with Tropical Cyclone Fred was located to the west of Senegal, causing considerable coastal damage in the southern Senegal-Gambia domain (south of Dakar, Senegal). Ten-meter winds from three Weather Research and Forecast model simulations were used to estimate zonal Ekman transport, when the maximum values were found on 30 August. These simulations are in agreement with limited coastal observations showing increasing southerly wind speeds during 30 August but overestimated relative to the three coastal stations. The strong meridional winds translate into increased zonal Ekman transport to the coast of Senegal on 30 August and are likely responsible for some coastal flooding. Ekman transport along the coast contributes significantly to the water-level variations during swell events. The use of a coupled ocean model will improve the estimates of Ekman transport along the Guinea-Senegalese coast. The observed damage suggests that artificial and natural barriers (mangroves) should be strengthened to protect coastal communities in Senegal.
\end{abstract}

Keywords Tropical cyclone $\cdot$ Weather Research and Forecast model $\cdot$ Ekman transport · Coastal flooding

\section{Introduction}

Coastal Resilience in West Africa and the nearby Islands of Cabo Verde is challenging because of mounting human drivers associated with population growth, socio-economic development, natural hazards, anthropogenic climate change, and limited observing systems. An estimated 100 million persons live along coastal West Africa and expected to increase throughout the twenty-first century rapidly. Most of the region has a limited observing network along coastlines and also over the oceans. Ship reports provide most of the real-time ocean and weather conditions between Cape Verde and Coastal West Africa, while the Prediction and Research Moored Array in the Tropical Atlantic (PIRATA) of buoys are sufficiently far from coastal zones in West Africa [1]. There are limited tidegauges and coastal weather stations along coastal West Africa. Automated weather stations in Cape Verde were critical to observing coastal flooding from Hurricane Fred, as well as from sea-level rise and natural hazards [2].

During the northern hemisphere summer season, African Easterly Waves (AEWs) move across West Africa every

Supplementary Information The online version contains supplementary material available at https://doi.org/10.1007/s42452-02104578-5.

$\triangle$ Abdou Lahat Dieng, abdoulahat.dieng@ucad.edu.sn | 'Laboratoire de Physique de l'Atmosphère et de l'Océan Siméon-Fongang, Ecole Supérieure Polytechnique, Université Cheikh Anta Diop, Dakar, Senegal. ${ }^{2}$ Ecole Supérieure des Sciences et Techniques de I'Ingénieur (ESTI), Université Amadou Mahtar Mbow, BP 45927, Dakar, Senegal. ${ }^{3}$ Department of Meteorology, The Pennsylvania State University, University Park, PA, USA. 
3-5 days and may be associated with flooding inland but can evolve further to tropical disturbances over the Atlantic Ocean $[3,4]$. Sometimes, an area of low pressure with a well-defined area of vorticity between $850-700 \mathrm{hPa}$ can develop after the AEWs exit the coast leading to a tropical depression or a named storm. They can then be the cause of loss of human life and material when they deepen near the coast. In 1999, the disturbance associated with Tropical cyclone Cindy was observed from Senegal and lead to more than 100 fatalities along the coast of Senegal and Mauritania [5]. Senegal is located in the Western Sahel, with a growing population of approximately 15 million residents. However, many of the residents live near the capital of Dakar, which is the westernmost city along the African Coast $(14.59 \mathrm{~N}, 17.5 \mathrm{~W})$. More than $20 \%$ of the Senegalese population lives in Dakar, although its area does not cover more than $0.5 \%$ of the country, according to the latest report from the National Agency for Statistics and Demography of Senegal (http://www.ansd.sn/). Senegal has a coastline of $706.72 \mathrm{~km}$ long [6] and has located in the southern part of the Canary Upwelling system (a typical Eastern Boundary Upwelling System (EBUS). The Senegalese upwelling season, which generally starts in October and ends in late May to early June, ensures a high level of primary production [7-11]. The Southern Senegal marine ecosystem is well known to be a spawning and nursery area for small pelagic fish species. Therefore, artisanal fishing is the first economic activity generating income in Senegal.

Two types of swells characterize the Senegalese coast: (1) In the northern zone (between St-Louis and Dakar), the trade winds and disturbances of the North Atlantic basin generate swells of north/northwest direction throughout the year. (2) In the southern zone (from Dakar to Cap-Skirring), swells are less frequent because northwest Atlantic swells are diffracted over the peninsula of Cape Verde (defined as the Region of Dakar) which considerably weakens them. However, swells occur mostly in NH summer period and can be generated by Mesoscale convective systems and/or African Easterly Waves which can deepen into tropical depressions off the coast $[2,5,12,13]$. The consequences can be disastrous for the populations living along the littoral. Indeed, this zone is characterized by a broad and shallow continental shelf (i.e., 20-30 m over tens of kilometers) compared to the northern zone $[8,14]$. The shallow depth of the ocean and the concave shape of Senegal's coastline can lead to the gradual advance of the sea, thereby increasing coastal population vulnerability to flooding during strong swell events.

Hurricanes rarely occur in the extreme Eastern Atlantic Ocean, but on 31 August 2015, Hurricane Fred passed through the Cape Verde Islands, causing damage in seven of the ten Islands [2]. This storm rapidly intensified from a tropical depression at 0000 UTC on 30 August to a hurricane 0000 UTC 31 August. However, prior to reaching Cape Verde, this storm caused seven fatalities associated with a fishing vessel and caused damage along Senegal's coastline. On 30 August 2015 reports by administrative authorities of Fatick region, which is in southwest Senegal, reported significant losses in the villages (Palmarin, Sessene, Dionewar, Ngallou, Diakhanor, Djifere, Cap Skirring) caused by a strong swell during the night of 30 August. They report that approximately 20 houses were destroyed, displacing many people. Further north, media reports suggest that more than 200 homes were damaged/destroyed along with boats. Residents that were interviewed in Bargny, Senegal, and the Hann District of Senegal spoke of the rise of the seas during the day of 30 August, leading to widespread destruction (Figure S1).

The objectives of this study are to use a set of fine grid spacing simulations using the Weather, Research and Forecasting (WRF) model to characterize the disturbance associated with TC Fred through the period of 29 and 30 August during its evolution. We then use WRF output from these simulations to estimate Ekman transport of water toward the coast of Senegal that could have been associated with coastal damage on 30 August 2015. This paper is organized as follows: the used data, model simulations and Ekman transport estimates are presented in Sect. 2. The results and conclusions are presented in Sects. 3 and 4 .

\section{Data and methodology}

\subsection{Data}

Based on satellite observations and model analysis, the National Hurricane Center (NHC) maintains a climatology of all Atlantic tropical cyclones since 1851 in the whole Atlantic and the Pacific, called HURDAT. For each storm, HURDAT contains estimates of the latitude, longitude, 1-min maximum sustained surface winds, minimum sealevel pressure with a precision of $0.18^{\circ}$ latitude/longitude, $2.57 \mathrm{~m} / \mathrm{s}$, and $1 \mathrm{mb}$, respectively [15] for every synoptic time $(0000,0600,1200$, and 1800 UTC). Here, the sixhourly positions are used to track the evolution of Hurricane Fred. These data were downloaded from the NHC website (https://www.nhc.noaa.gov/). The new gridded Daily Advanced Scatterometer (DASCAT) wind and wind stress data are used to examine $10 \mathrm{~m}$ wind associated with Fred genesis. Data are estimated over global oceans from Advanced Scatterometer Data Products (ASCAT) retrievals using objective methods and have a spatial resolution of $0.25^{\circ}$ in longitude and latitude. The calculation of daily estimates uses ascending/descending tracks available and valid retrievals. According to the ASCAT sampling scheme, 
the objective method allowing the determination of regular in space and surface wind fields uses ASCAT observations as well as ECMWF analyses. The latter is considered as the temporal interpolation basis of ASCAT retrievals [16]. More details about data, objective method, computation algorithm may be found in [17].

Satellite Brightness temperature data of the thermal infrared channel $(10.8 \mathrm{~mm})$ is produced by the Climate Prediction Center (CPC), NOAA National Centers for Environmental Prediction. The data are provided in netCDF-4 format on a 4-km-equivalent latitude/longitude grid over the latitude band $60^{\circ} \mathrm{N}-\mathrm{S}$.

ERA-Interim is a global atmospheric reanalysis produced by the European Centre for Medium-Range Weather Forecasts (ECMWF). It is produced with a sequential data assimilation scheme, advancing forward in time using 12hourly analysis cycles. In each cycle, available observations are combined with prior information from a forecast model to estimate the evolving state of the global atmosphere and its underlying surface. The spatial resolution of the data set is approximately $80 \mathrm{~km}$ (T255 spectral) on 60 levels in the vertical from the surface up to $0.1 \mathrm{hPa}$ [18]. The new high-resolution Reynolds sea surface temperature (SST) data is used to analyze the SST pattern associated to Hurricane Fred. The data are stored on a spatial resolution of 0.25 -degree and a temporal resolution of 1 day. The information about the interpolation method used to conduct is described in [19].

The winds measured at Dakar Yoff (located at $14^{\circ} 44^{\prime}$ $\mathrm{N}, 17^{\circ} 30^{\prime} \mathrm{W}, 27 \mathrm{~m}$ above ground) are representative of the winds over Southern Senegal $[8,9]$. They are also used to evaluate the Weather Research and Forecasting (WRF) model's ability to reproduce the surface wind circulations over the southern Senegalese coast. The tide gauge data of Dakar station from 1993 to 2019 is used to analyze the sea-level rise during the passage of Hurricane along the Senegalese coast. Data are retrieved from http://uhslc. soest.hawaii.edu/data/?rq

The variables presented above are used to analyze the atmospheric conditions occurring during the genesis of Hurricane Fred, but also to analyze the capacity of the WRF model to reproduce the event.

\subsection{Methodology}

Recent case studies based on observations have shown that Ekman transport can have a strong effect on coastal flooding especially when the storm moves slowly, the storm-induced winds are parallel to the coast [20-22]. Ekman transport has been cited as one of the key mechanisms causing subtidal water level fluctuation inside the Chesapeake Bay for a wind forcing longer than 4 days [23]. Based on a 3D storm surge model of the Chesapeake Bay,
Shen and Gong [20] studied the impact of model domain size, wind directions and Ekman transport on the storm surge of the extratropical cyclone Ernesto (2006) in the Chesapeake Bay. Their results show that the Ekman setup along the coast contributes significantly to the waterlevel variations during storm events. It enhances (reduces) surge inside the Bay under the wind forcing from $\mathrm{N}$ and NE (SW, S, and SE) directions. By using a set of data from an ADCP station placed at a depth of $65 \mathrm{~m}$ on the sea bed off the coast at Sète, supplemented by the ocean circulation model SYMPHONIE, Michaud et al. [22] studied the hydrodynamics in the Gulf of Aigues-Mortes (NW of the Gulf of Lion) during the storm of 18 February 2007. They showed that "the duration of the storm (about $36 \mathrm{~h}$ at the apex) explains the continuous increase of the current as predicted by the theory. The frictionally induced Ekman transport explains the current shear in the surface layer in the rising stage of the storm, and the addition of high waves and strong wind at the apex is more in favor of strong vertical mixing in the surface layer."

To examine the role of Ekman Transport, we use the Weather Research and Forecasting (WRF) model output, which has an outer $12 \mathrm{~km}$ grid spacing domain and an inner $4 \mathrm{~km}$ grid spacing domain. We use the WRF version 3.71 [24] in this study to examine the tropical disturbance off the coast of West Africa. The National Center for Environmental Prediction (NCEP) final analyses FNL is used to initialize and provide boundary conditions using FNL analyses for the parent domain at $12 \mathrm{~km}$ every $6 \mathrm{~h}$. Three simulations using two domains are used in simulating TC Fred. The simulations are started at different times beginning on 28 August 0000 UTC and initialized every $12 \mathrm{~h}$ (Table 1). The coarse grid has $12 \mathrm{~km}$ grid spacing with 31 vertical levels, 251 east-west grid points, and 181 north-south grid points covering much of West Africa and the extreme Eastern Atlantic (Fig. 1a). The fine grid uses $4 \mathrm{~km}$ grid spacing with 31 vertical levels, 196 east-west points, and 160 north-south points covering Senegal and extreme Eastern Atlantic (Table 1). The fine grid simulations begin $6 \mathrm{~h}$ after the coarse grid simulation is initiated. There is two-way feedback used between the coarse and fine grid domains.

Table 1 WRF simulations undertaken for this study, with grid spacing, start and end times

\begin{tabular}{llll}
\hline Simulation & Start time & End time & Grid spacing \\
\hline D1A & 28080000 UTC & 31080000 UTC & $12 \mathrm{~km}$ \\
D2A & 28080600 UTC & 31080000 UTC & $4 \mathrm{~km}$ \\
D1B & 28081200 UTC & 31080000 UTC & $12 \mathrm{~km}$ \\
D2B & 28081800 UTC & 31080000 UTC & $4 \mathrm{~km}$ \\
D1C & 29080000 UTC & 31080000 UTC & $12 \mathrm{~km}$ \\
D2C & 29080600 UTC & 31080000 UTC & $4 \mathrm{~km}$
\end{tabular}


Fig. 1 a Map of West Africa including the simulation domains and the orography. The red larger represents the domain 1 and the smaller red rectangle is for domain 2 . $\mathbf{b}$ Bathymetry (in dashed line) and location of observed damages (in red point) during the passage of the Hurricane Fred along the Senegalese coast

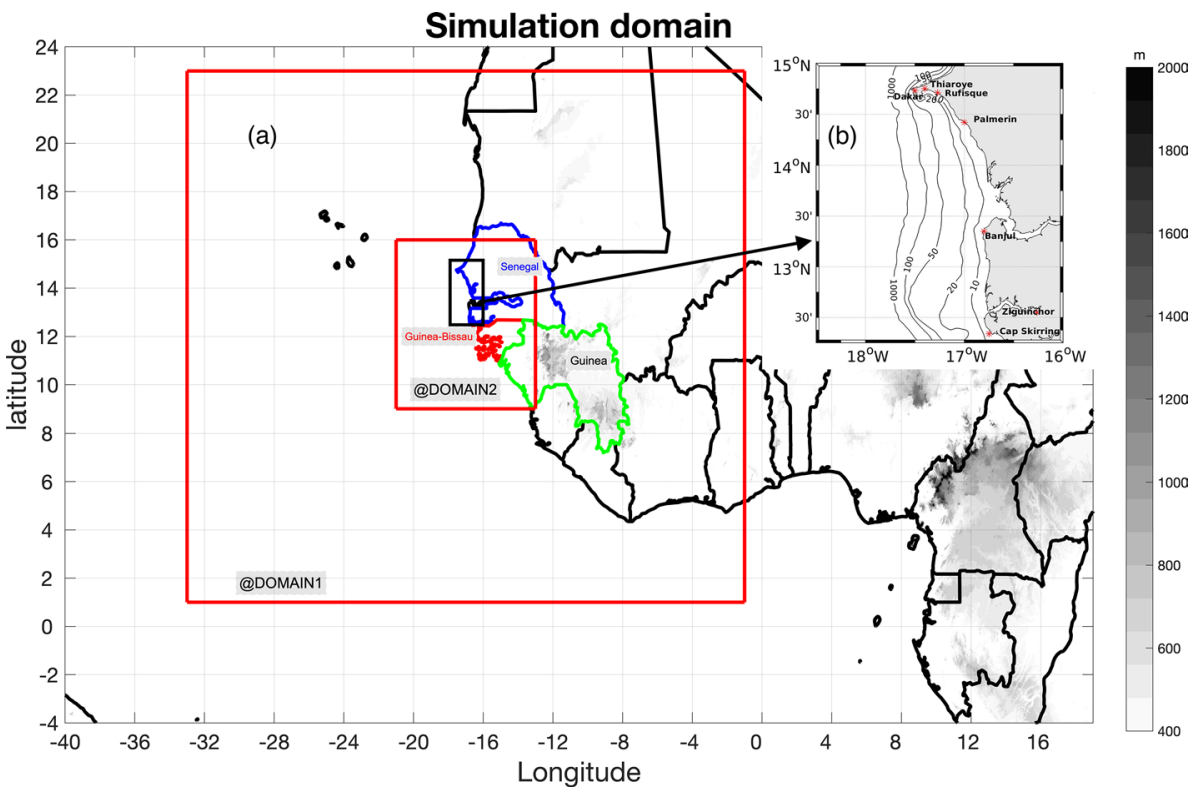

The larger domain uses the Kain-Fritsch cumulus parameterization [25], while the inner domain does not use a cumulus parameterization; Thompson microphysics [26] is used in the outer and inner domains.

Surface stresses $\left(\tau_{x}\right.$ and $\tau_{y}$ ) are computed from WRF simulated ten-meter wind components and used to estimate the zonal and meridional Ekman transport with a focus on 30 August 2015 at various locations along the Senegalese coast (Fig. 1b). We computed Ekman transport $\left(\mathrm{Q}, \mathrm{m}^{3} \cdot \mathrm{s}^{-1} \cdot \mathrm{m}^{-1}\right)$ using a constant atmospheric density ( $\rho a=1.2 \mathrm{~kg} \mathrm{~m}-3$ ), a dimensionless empirical drag coefficient $\left(\mathrm{Cd}=1.3 \times 10^{-3} ;[10]\right.$, the empirical formulation of wind stress, a constant sea water density ( $r h o=\rho=1000 \mathrm{~kg} \mathrm{~m}-3$ ) and the Coriolis parameter $\mathrm{f}$ as follows:

$\tau_{x}=\rho_{a} \cdot C_{d} \cdot \sqrt{u^{2}+v^{2}} \cdot u$

$\tau_{y}=\rho_{a} \cdot C_{d} \cdot \sqrt{u^{2}+v^{2}} \cdot v$

$Q_{x}=\frac{\tau_{y}}{f \cdot \rho}$

$Q_{y}=\frac{-\tau_{x}}{f \cdot \rho}$

In these two formulations above, the $Q_{x}$ and $Q_{y}$ correspond to the zonal and meridional Ekman transport components, respectively.

In order to assess the effect of Ekman transport during the period 30-31 of August on the Senegalese coast, we calculated Accumulated Ekman Transport (AET) which is the time-integrated Ekman transport using the following formula

$\mathrm{AET}_{x}=\int_{T_{1}}^{T_{2}} Q_{x} \cdot \mathrm{d} T$

$\mathrm{AET}_{y}=\int_{T_{1}}^{T_{2}} Q_{y} \cdot \mathrm{d} T$

where $\mathrm{AET}_{x}$ and $A E T_{y}$ correspond to the zonal and meridional Accumulated Ekman Transport components, respectively. $T_{1}$ and $T_{2}$ are the initial and the final dates, respectively.

\section{Results}

\subsection{Environmental conditions of the genesis of Fred}

On 28 August 2015, a mesoscale convective system embedded in an AEW trough from Mali moved into southeastern Senegal (Fig. 1a, b). It moved slowly, crossing the Guinea Highlands (located around $11^{\circ} \mathrm{N}, 12^{\circ} \mathrm{W}$ ), and arrived at the coast between 29th 1200 UTC and 30th 0000 UTC. During this time, there was a closed cyclonic circulation at $700 \mathrm{hPa}$. Convection gradually strengthened during the day of 30 August, with AEW remaining almost stationary near the Senegal and Guinea coasts. From 30th to 31 August, the convection increases in scale, and there is a strengthening vortex at $700 \mathrm{hPa}$ (Fig. 2d-f). Observations show that the surface cyclonic circulation began to form during the same period, and the system was classified as 

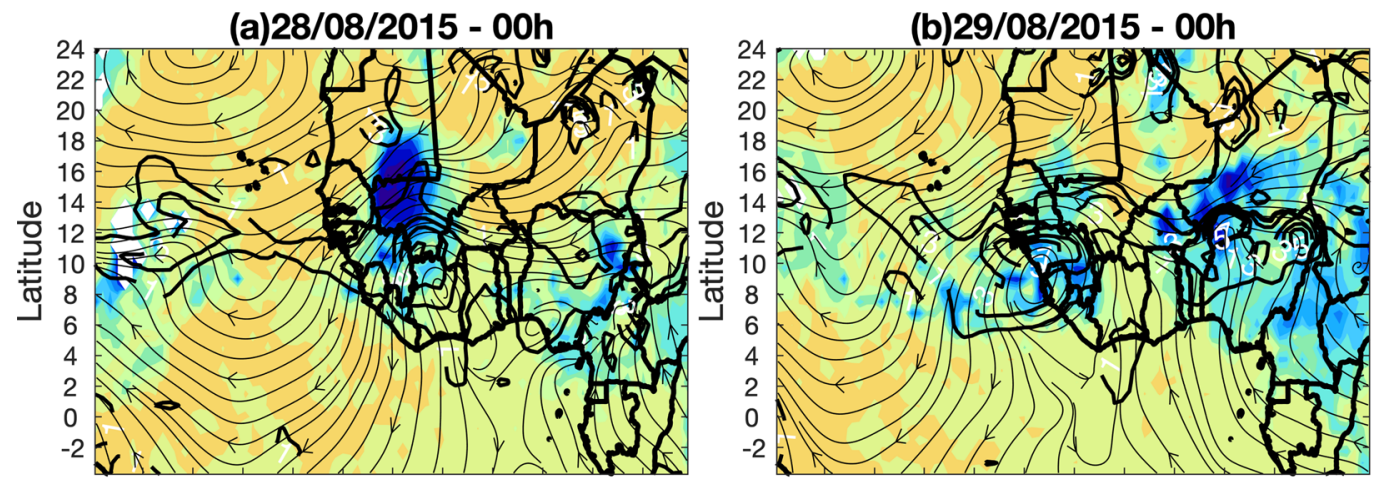

(c) $29 / 08 / 2015$ - 12h
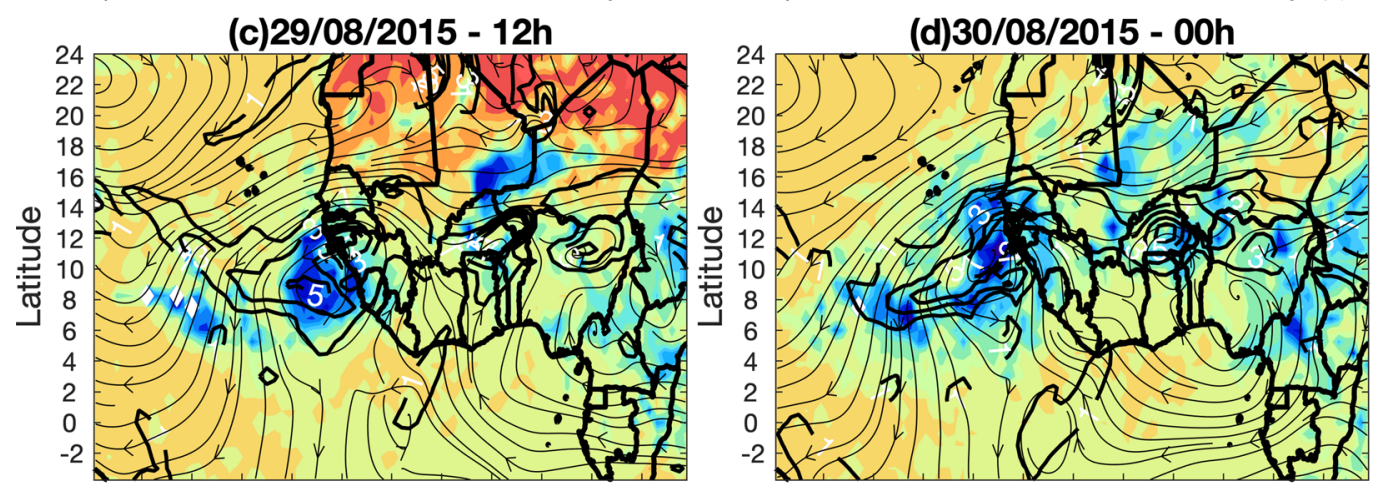

\section{${ }^{\mathrm{O}} \mathrm{C}$}
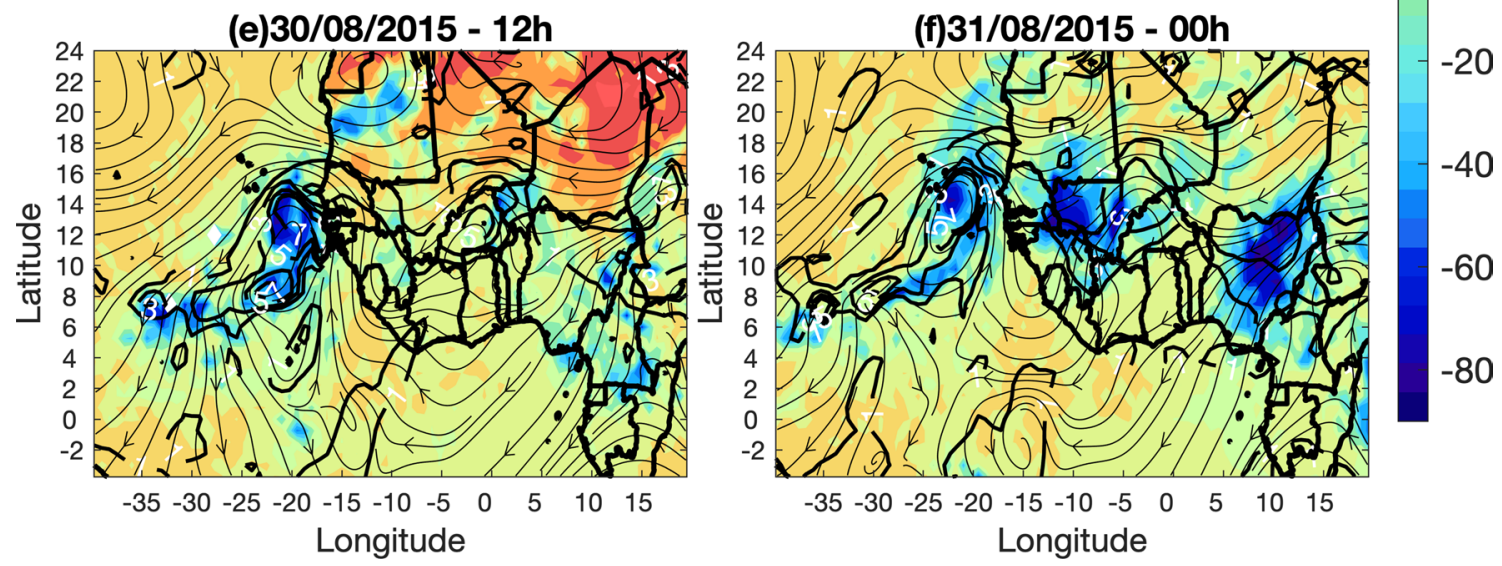

Fig. 2 Meteosat Second Generation brightness temperature (in color, units in Degree C), Era Interim $700 \mathrm{hPa}$ wind (in streamline) and positive relative vorticity (contours greater than $1.10^{-5} \mathrm{~s}^{-1}$ )

a tropical depression by the NHC about 0000 UTC on 30 August. The wind sensor of "Melax the buoy" (only Senegalese Buoy) located at $400 \mathrm{~km}$ north $\left(14^{\circ} 20^{\prime} \mathrm{N}, 17^{\circ} 14^{\prime} \mathrm{W}\right)$ of the disturbance also observed the effects of the tropical depression with surface wind speed records of $12 \mathrm{~m} / \mathrm{s}$ (about 24 knots), associated with the intensification of the disturbance (figure not shown).

The disturbance developed in a favorable environment with ocean surface temperature higher than $28{ }^{\circ} \mathrm{C}$ (Fig. 3a) and low vertical wind shear (figure not shown). During 30 and 31 August, the system intensifies further to reach a category 1 hurricane on the SaphirSimpson scale before reaching the Cape Verde Islands, a showing the evolution of the disturbance that gave rise to the Hurricane Fred off the Senegal-Guinean coast

situation that was never encountered during the twentieth century with some evidence suggesting a hurricane in 1892 [2].

Figure $3 \mathrm{~b}, \mathrm{c}$ shows DASCAT wind fields on 30 August and 31 August. Southerly winds occur near the Senegalese coast on 30 and 31 August. Winds of more than 25 knots $\left(\sim 12.5 \mathrm{~m} \mathrm{~s}^{-1}\right)$ are persistent during this period. The southerly fetch extends for more than $500 \mathrm{~km}$ for both days, which could increase the wave heights beyond $4 \mathrm{~m}$ on the coastlines to the south of Dakar, especially during the morning hours of 31 August. 


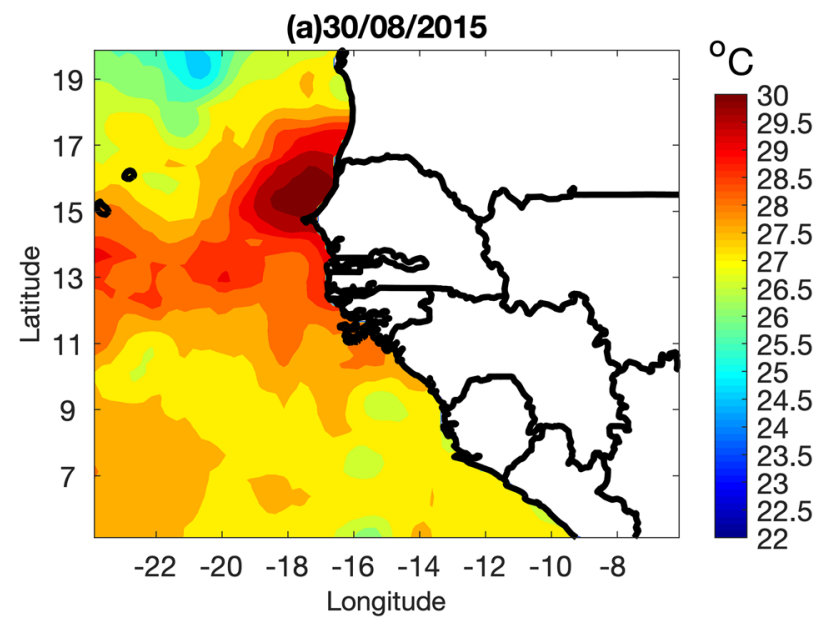

(b) $30 / 08 / 2015$

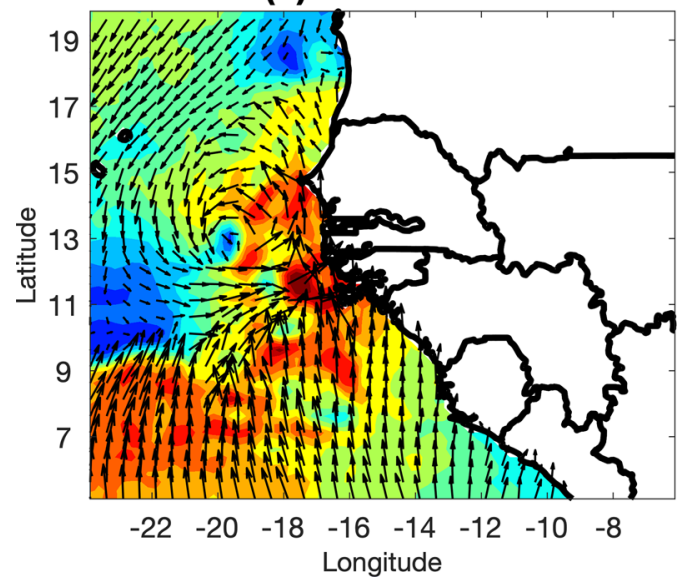

(c)31/08/2015

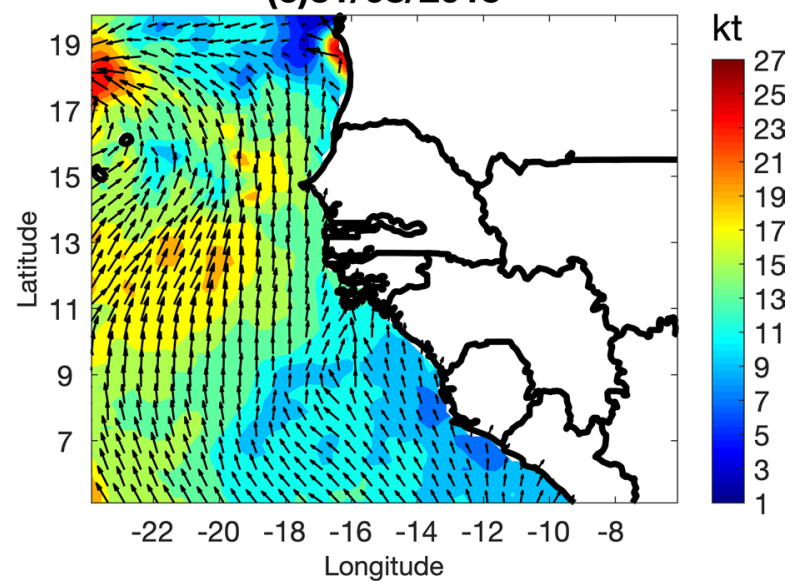

Fig. 3 a Mean daily Sea Surface Temperature for 30 August. Units in Degree C. Data are from https://psl.noaa.gov/data/gridded/data.noaa. oisst.v2.highres.html. Mean daily $10 \mathrm{~m}$ wind (color and vector, in knots) in $\mathbf{b}$ for 30 August and in $\mathbf{c}$ for 31 August

\subsection{Model evaluation}

Tracks of the simulated disturbance relative to the NHC best track are presented in Fig. 4. The black solid line shows the NHC evolution and track of tropical disturbance associated with Fred making the closest approach to West Africa near the Guinea-Bissau at 0000 UTC 30 August. Throughout the day, TC Fred is located several hundred kilometers off the coast of Senegal, and by 000031 August, the center of then Hurricane Fred is located approximately at 4.2 degrees west of Dakar, according to NHC archives. In all of the simulations, the forecasted location of the storm is behind the official NHC location. Simulation D2A, which began on 28 August, shows a track that is closest to the $\mathrm{NHC}$ track. However, its position at 0000 UTC 31 August is to the southeast of the actual location. It is approximately
$6 \mathrm{~h}$ behind the NHC position and located near the estimated NHC position at 1800 UTC, 30 August. The track of simulation D2B, which began at 180028 August, is displaced to the east of the NHC official track and located much closer to the Guinea-Bissau and Senegalese coastlines. It is also displaced in time and occupies a latitude similar to NHC. The third simulation, D2C, began at 0600 , 29 August, and is displaced to the west of the NHC position. It also occupies a biased position and is located at $14^{\circ}$ $\mathrm{N}$, similar to the other two simulations at 000031 August. The differences in the simulated position of TC Fred, provided a useful means of evaluating coastal winds and the Ekman transport at the Palmerin, Rufisque, and Thiaroye Senegal, which are at or near locations where damage occurred (Figure S1). 
Fig. 4 Evolution and track of tropical disturbance associated with Fred from 30 August, 2015 at 0000 UTC to 31 August, 2015 at 0000 UTC. Black solid line is $\mathrm{NHC}$ data, blue dashed line for simulation $2 A$, red dashed line for simulation $2 \mathrm{~B}$ and green dashed line for simulation $2 \mathrm{C}$

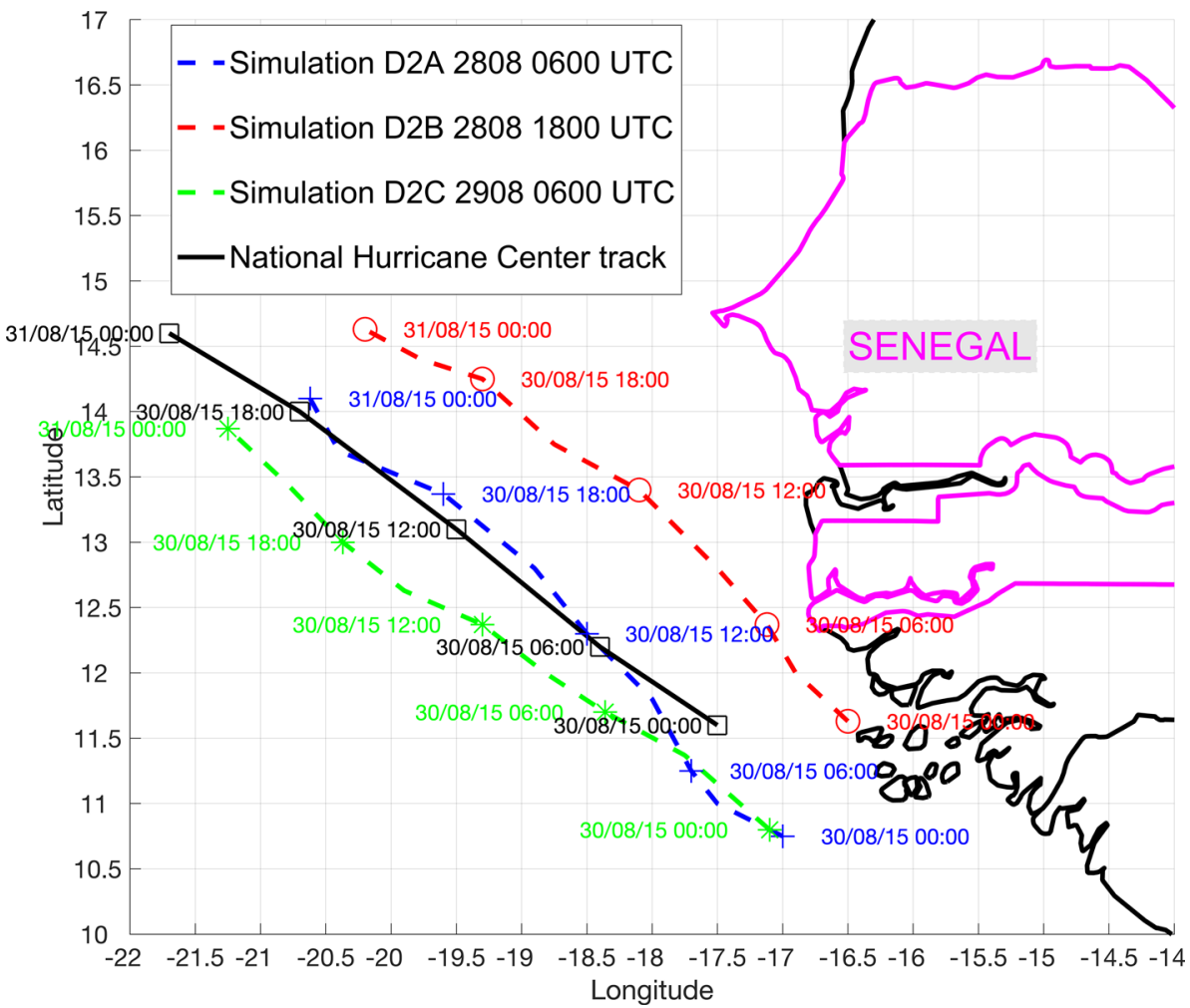

Figure 5a-f represents $10 \mathrm{~m}$ wind on 30 August 2015, respectively, at 0600 UTC and 2000 UTC. Simulated disturbances at 0600 UTC 30 August are located between 11 and $12.5 \mathrm{~N}$ in the three simulations (Fig. $5 \mathrm{a}, \mathrm{C}, \mathrm{e}$ ). The simulated center of the disturbance in $\mathrm{D} 2 \mathrm{~B}$ is located closest to the coast $(12.3 \mathrm{~N}, 17 \mathrm{~W})$, while the center in $\mathrm{D} 2 \mathrm{C}(11.7 \mathrm{~N}, 18 \mathrm{~W})$ is located the furthest out to sea; the center of the disturbance in D2A is located further south near $11.3 \mathrm{~N}$. Winds of 30-40 knots are simulated in all simulations but cover a larger area in simulations D2A and D2B. At 2000 UTC, the centers of the simulated storms are located near $13.5 \mathrm{~N}, 20.5 \mathrm{~W}(\mathrm{D} 2 \mathrm{~A}), 14.5 \mathrm{~N}$, $20 \mathrm{~W}$ (D2B), and $13.5 \mathrm{~N}, 21 \mathrm{~W}$ (D2C) (Figs. 5b, d, f). The strongest winds of 40-50 knots are found near the center of the simulated disturbances. The three simulations show strong southerly winds ( $20-30$ knots) along the Senegalese coastlines at 2000 UTC. In the regions where damages were reported, southerly winds would drive waves northward toward the Senegalese coast.

Figure $6 \mathrm{a}, \mathrm{b}$ shows the observed and simulated meridional wind component at selected locations along coastal Senegal and WRF meridional winds averaged over the nearest grid point of Dakar observation.
It should be noted that, except for Dakar, all the other stations present discontinuities synonymous with a lack of data (Fig. 6a). At the southernmost station of Cap Skirring, a rapid transition to southerly winds is found on 30 August, beginning at 0600 UTC. Stations located further north also show a pattern of southerly winds after 0600 UTC at Banjul, Gambia, Dakar, and Ziguinchor Senegal. The wind speeds of 10-15 knots are found at Cap Skirring after 0600 UTC, while winds of 10 to 15 knots are found after 1200 UTC in Dakar, Senegal. This pattern of observed southerly winds between Cap Skirring and Dakar, Senegal (distance 142 nautical miles or $263 \mathrm{~km}$ ) would have created fetch that could have led to significant wave heights in coastal zones based on the Sverdrup-Monk-Bretschneider Nomogram (Kelvin Rodolfo [27].

Simulated winds (Fig. 6b) in Dakar also show a pattern of southerly winds in agreement with observations. Simulation D2A shows continuous southerly winds beginning at approximately 0500 UTC, 30 August, and continuing throughout the day. The winds reach the maximum value of 18 knots between 1600 and 2200 UTC. Simulation D2B shows a short period of southerly winds but produces the 
(a) AUG 30 0600 UTC $10 \mathrm{~m}$ Wind Mag (knots)
$10 \mathrm{~m}$ streamlines initialized 28 Aug 0600 UTC

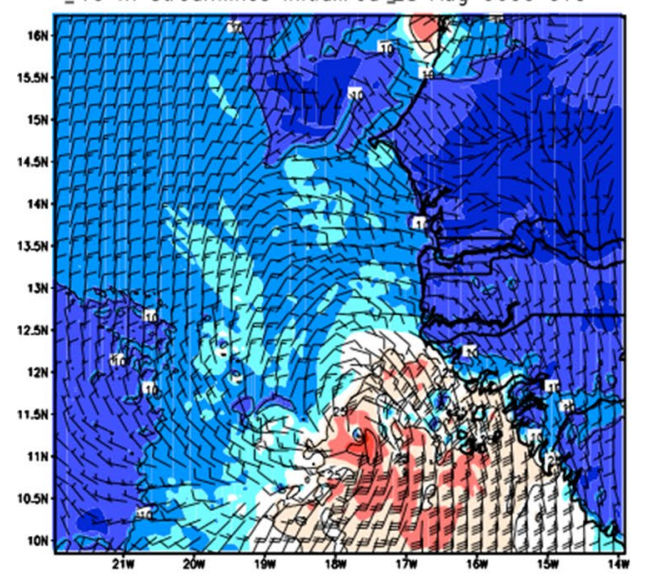

(c) AUG 300600 UTC $10 \mathrm{~m}$ Wind Mag (knots) $10 \mathrm{~m}$ streamlines initialized 28 Aug 1800 UTC

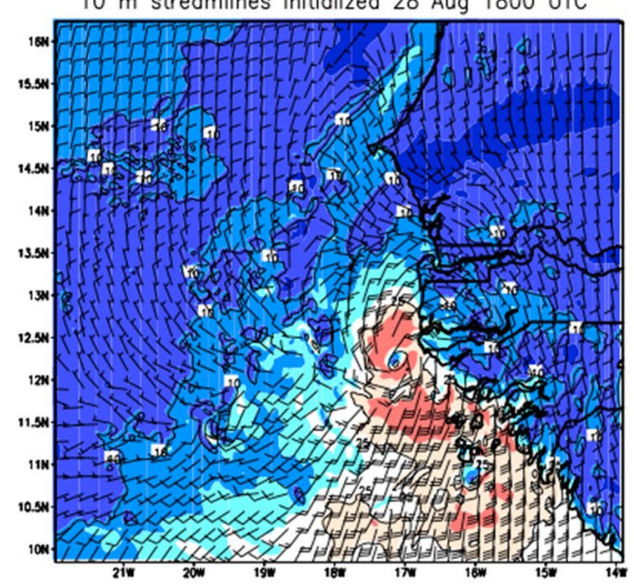

(e) AUG 300600 UTC $10 \mathrm{~m}$ Wind Mag (knots) $10 \mathrm{~m}$ streamlines initialized 29 Aug 0600 UTC

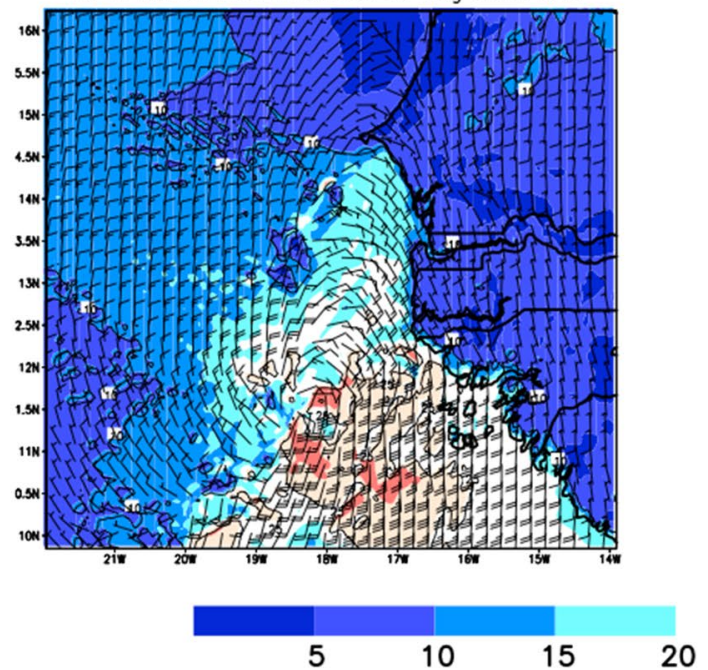

(b) AUG 302000 UTC $10 \mathrm{~m}$ Wind Mag (knots) $10 \mathrm{~m}$ streamlines initialized 28 Aug 0600 UTC

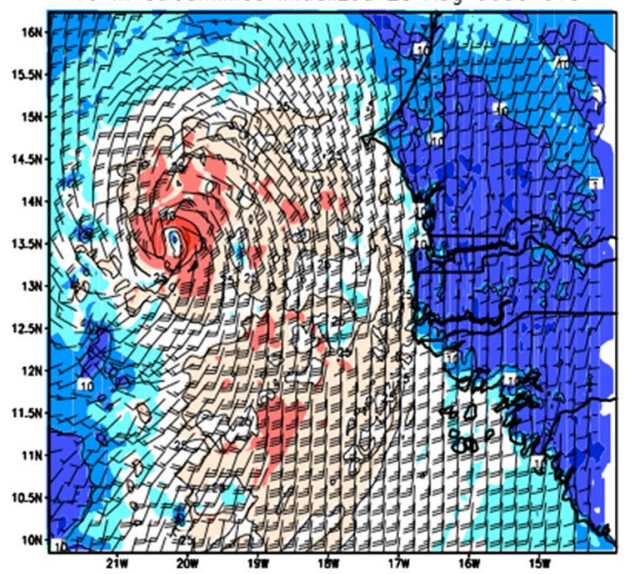

(d) AUG 302000 UTC $10 \mathrm{~m}$ Wind Mag (knots) $10 \mathrm{~m}$ streamlines initialized 28 Aug 1800 UTC

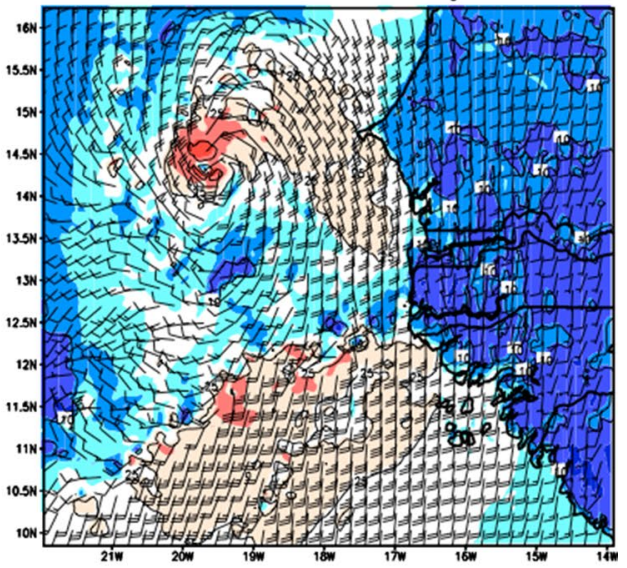

(f) AUG 302000 UTC $10 \mathrm{~m}$ Wind Mag (knots) $10 \mathrm{~m}$ streamlines initialized 28 Aug 1800 UTC

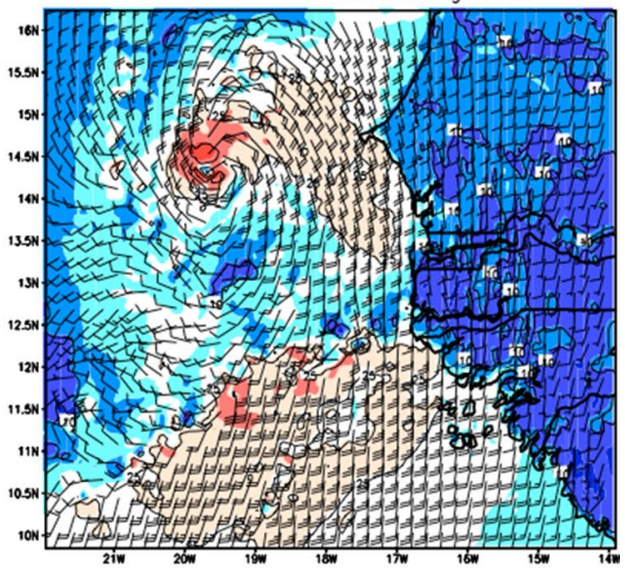

30

Fig. 5 Simulated 10 m-winds (color and arrows in kt) on 30 August 2015, respectively, from left to right at 0600 UTC and 2000UTC. Top for simulation $2 \mathrm{~A}$, middle for simulation $2 \mathrm{~B}$ and bottom for simulation $2 \mathrm{C}$ 

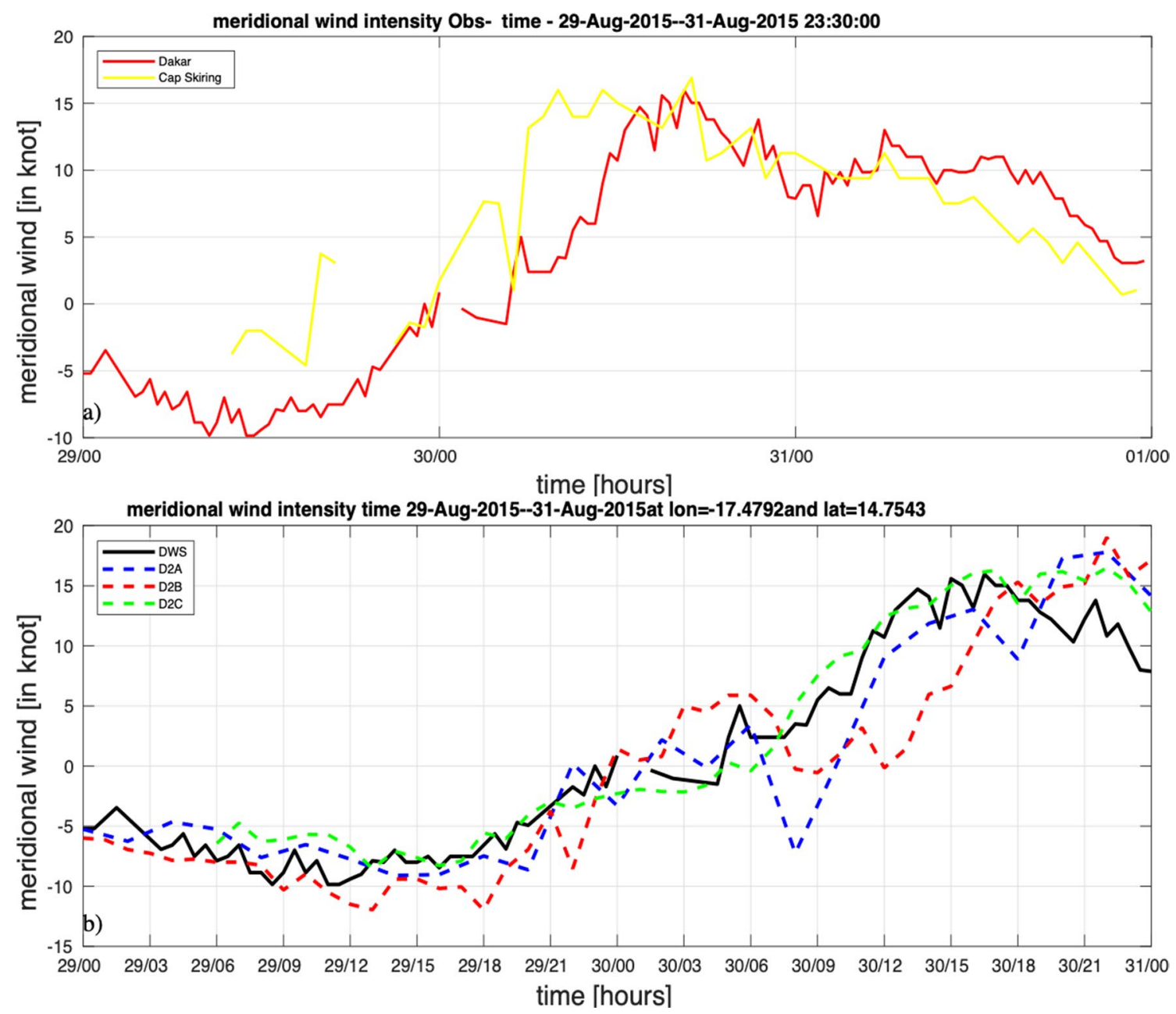

Fig. 6 a observed Meridional wind (kt) at Dakar (red) and Cap Skiring (yellow) from 29 August, at 00:00 UTC to 31 August 29 at 00:00 UTC, b simulated WRF meridional winds averaged over the nearest grid point of Dakar observation and during the same period

strongest simulated meridional winds of more than 19 knots between 2100 and 2300 UTC on 30 August. While the simulated disturbance is located furthest west relative to the other simulations, it simulated southerly winds beginning the earliest (0400 UTC on 30 August) and increases throughout the day, reaching its largest values between 1700 and 2200 UTC.

\subsection{Zonal Ekman transport estimation}

The Ekman transport, which is determined from simulated zonal and meridional wind components at grid-point locations near Palmerin, Rufisque, and Thiaroye (see Fig. 1b), is estimated using the Eqs. $(3,4)$. Zonal Ekman transport indicates increasing eastward transport toward the coastline after 1200 UTC, 30 August, based on D2A and D2B (Fig. 7a-C). The largest transport occurs after 1800 UTC and as in a blue dashed line for simulation $2 \mathrm{~A}$, red dashed line for $2 \mathrm{~B}$ and green dashed line for $2 \mathrm{C}$. The solid black line represents the observed meridional wind at Dakar

is found at Rufisque relative to the other coastal locations in these simulations. Zonal transport estimated by simulation D3C is smaller relative to D2A and D2B. However, all of the transport is eastward in this simulation, with the largest values found around 000030 August and steady westward transport between 0900 and 2000 UTC 30 August.

Figure 8 shows varied Accumulated Ekman Transport (AET) between 30 and 31 August from the three simulations. The accumulated Ekman transport computed from simulation D2A occurs to the south of Senegal (Fig. 8a), while a higher accumulated Ekman transport is found in D2B and D2C along the Senegalese coastline (Fig. 8b, c). The largest accumulated Ekman transport along the Senegalese coastline occurs in $2 \mathrm{~B}$, which has to closer track to the coast.

Figure 9 shows the temporal series of the tide gauge data of Dakar station (longitude $=-17.42^{\circ} \mathrm{W}$, 

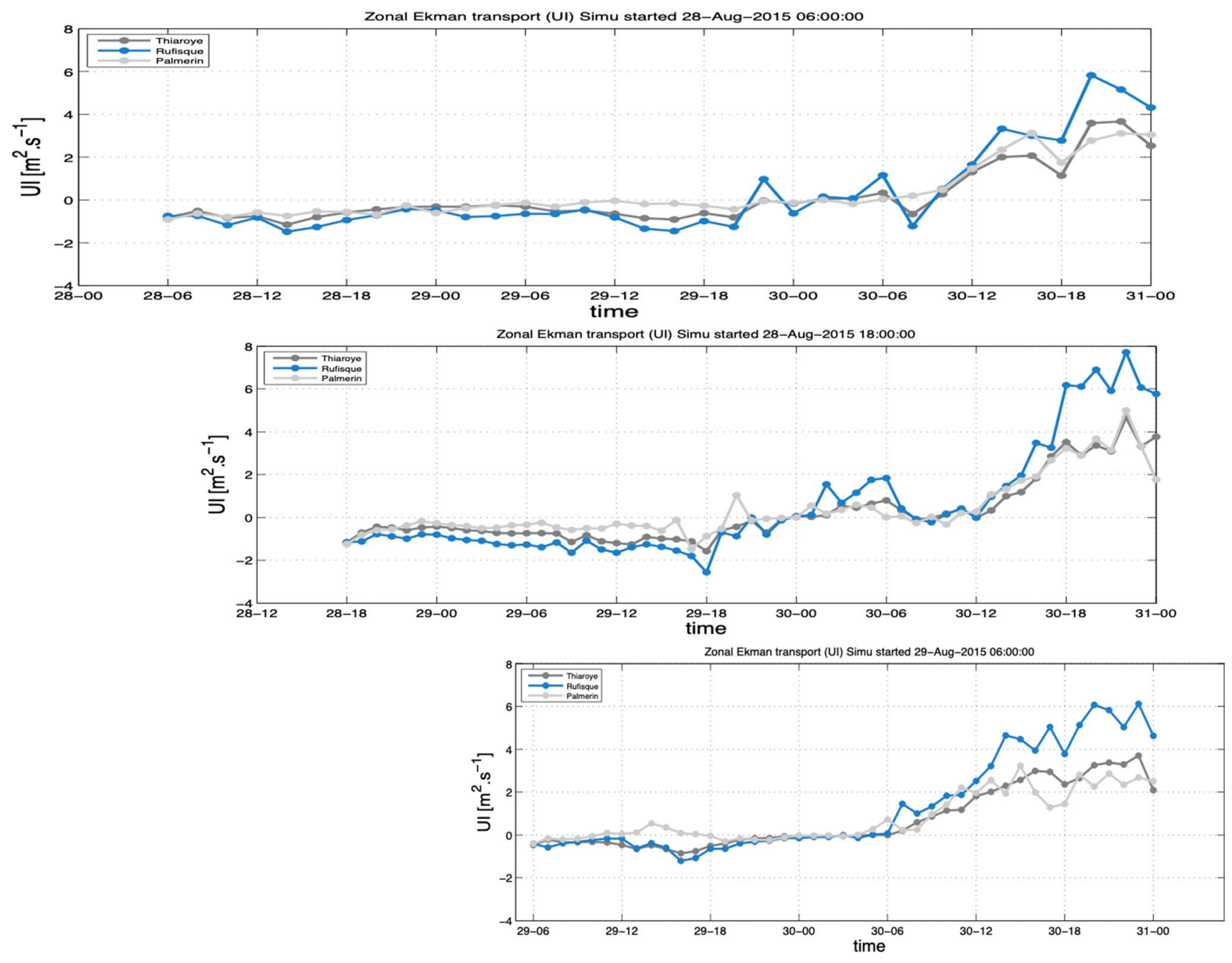

Fig. 7 Computed Zonal Ekman transport $\left(\mathrm{m}^{3} \cdot \mathrm{s}^{-1} \cdot \mathrm{m}^{-1}\right)$ at grid-point locations near Palmerin, Rufisque, and Thiaroye (see Fig. 1b)

latitude $=14.67^{\circ} \mathrm{N}$ ) from 1993 to 2019 . It reveals the seasonal variability of the sea level due to the southern Senegalese Upwelling variability [9]. However, the maximum height measured during this period is $1.35 \mathrm{~m}$. This value corresponds to the date of passage of Hurricane Fred.

\section{Conclusion}

During the evening of 30 August and likely into the early morning hours, residents along the coast of Senegal from Dakar through Palmarin experienced coastal flooding and infrastructure damages associated with the tropical disturbance that became Hurricane Fred. The flooding occurred when the tropical disturbance was developing but several hundred km away from the coast. Discussions with residents of Bargny (located near Rufisque) spoke of rising seas throughout the night and early morning hours, which caused the damage. Additional damage in the surrounding areas of Rufisque may have occurred (Ndoye, personal observation) but not reported. In this work, we used the WRF model to examine the potential impact of the tropical disturbance with a focus on 30 August 2015. The three simulations show a spread in the storm tracks relative to the NHC official track, with simulation D2A, which was initiated on 28 August 0000 UTC having the smallest track errors. Simulation D2B had an eastward bias, while simulation D2C had a westward bias.

Observations between Dakar and southern Senegal and including the Gambia show southerly winds during the morning through the night of 30 August, with model simulations showing agreement with the coastal observations. 

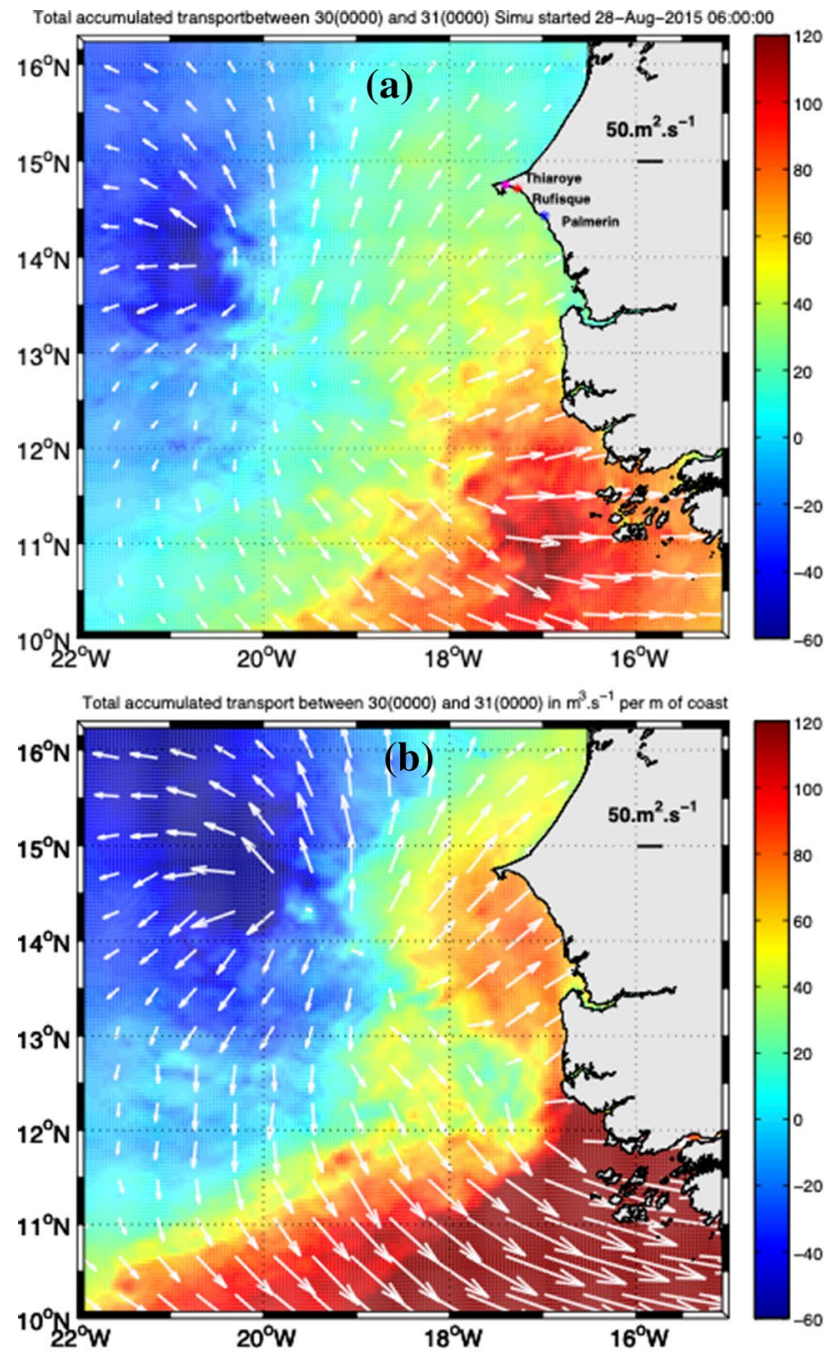

Total accumulated transportbetween 30(0000) and 31(0000) Simu started 29-Aug-2015 06:00:00

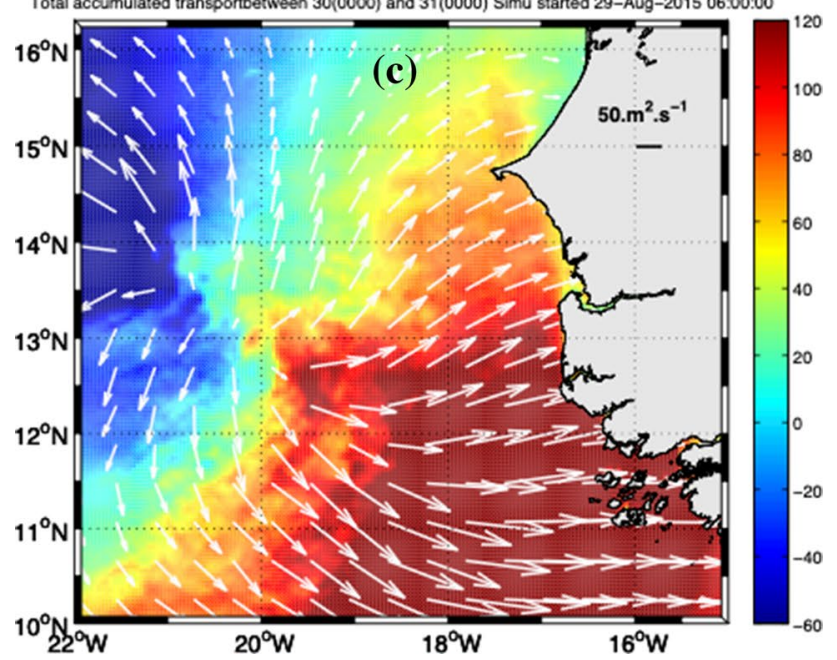

Fig. 8 Zonal component of the accumulated Ekman transport in color from 30th to 31 st august for $2 \mathrm{~A}$ (top), $2 \mathrm{~B}$ (middle) and $2 \mathrm{C}$ (bottom). Total accumulated Ekman transport is represented in vectors
Satellite overpasses show winds greater than 15 knots along coastal Senegal on 30-31 August, which would likely create a long fetch. The southerly winds may have impacted the coast of Senegal through eastward Ekman transport. High winds, and accumulated Ekman transport produces a storm surge, which is usually well above the high-tide level. The use of a Munk-Sverdrup-Bretschneider nanogram (a diagram used to estimate wave height based on hours of fetch and wind speed) suggests that a fetch of more $400 \mathrm{~km}$ for more than $24 \mathrm{~h}$ with wind speeds of 20 knots would produce wave heights of more than $2 \mathrm{~m}$ along coastal zones south of Dakar, Senegal. The largest accumulated Ekman transport along the Senegalese coastline occurs in $2 \mathrm{~B}$ (see Fig. 8), which has to closer track to the coast is in agreement with the high value of sea-level at the tide gauge station. This reveals the clear relationship between Ekman transport and sea-level rise.

The simulations associated with this tropical disturbance show that the damaging waves could occur even if the storm is not close to the Senegal coast. The shape of the Senegal coasts makes it vulnerable to strong southerly winds with a long fetch and over a long period. Similarly, [28] show that anti-cyclonic and cyclonic systems are responsible for extreme waves in the British Isles. In Senegal, south of Dakar, developing low pressure associated with African Easterly Waves during the summer can produce southerly winds and thus serve as the source of extreme waves. High pressure can produce northerly winds and would serve as the source of extreme waves in coastal regions to the north of Dakar. These weather events can be predicted with some degree of success, although the prediction of tropical cyclo-genesis is still challenging across the extreme eastern Atlantic Ocean. 


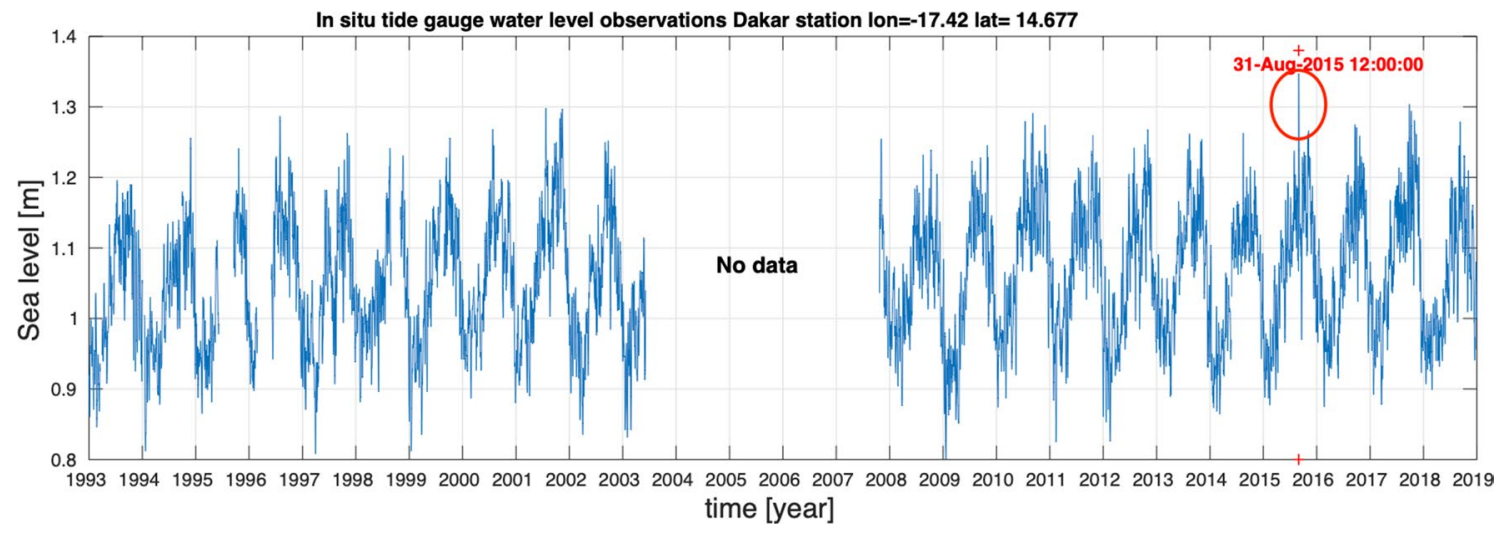

Fig. 9 Temporal series of the tide gauge data of Dakar station (longitude $=-17.42^{\circ} \mathrm{W}$, latitude $=14.67^{\circ} \mathrm{N}$ ) from 1993 to 2019

Increased Earth observations and predictive weather and wave models provide the best means of understanding events that cause coastal damage along West Africa. Such a system can provide the basis for developing a coastal warning system to protect the millions of people that live in coastal zones in West Africa in large cities, small towns, and fishing villages. The present challenge is to increase in situ coastal data, which has limited real-time buoy data and coastal weather station data. These data are needed to monitor extreme events, evaluate and improve satellite-based products, weather, and wave models.

Acknowledgements We thank the two anonymous reviewers for their comments on the manuscript. This work was supported by UK Research and Innovation as part of the Global Challenges Research Fund, grant number NE/P021077/1. The reanalysis data were obtained from the Institut Pierre Simon Laplace (IPSL; http://www. ipsl.fr/), WRF simulations were undertaken at Penn State University's Department of Meteorology and DASCAT data were obtained from the Centre de Recherche et d'Exploitation Satellitaire (CERSAT), at IFREMER, Plouzané (France). Wind data from Dakar weather station were downloaded at www.ogimet.com/metars.phtml.en. S.N. was supported by the AMMA 2050 innovative fund (SCUS-2050 project grant number M0220428/1).

Open Access This article is licensed under a Creative Commons Attribution 4.0 International License, which permits use, sharing, adaptation, distribution and reproduction in any medium or format, as long as you give appropriate credit to the original author(s) and the source, provide a link to the Creative Commons licence, and indicate if changes were made. The images or other third party material in this article are included in the article's Creative Commons licence, unless indicated otherwise in a credit line to the material. If material is not included in the article's Creative Commons licence and your intended use is not permitted by statutory regulation or exceeds the permitted use, you will need to obtain permission directly from the copyright holder. To view a copy of this licence, visit http://creativecommons. org/licenses/by/4.0/.

\section{References}

1. Foltz GR, Schmid C, Lumpkin R (2018) An enhanced PIRATA dataset for tropical Atlantic Ocean-atmosphere research. J Clim 31:1499-1524. https://doi.org/10.1175/JCLI-D-16-0816.1

2. Jenkins GS, Brito E, Soares E et al (2017) Hurricane Fred (2015): Cape Verde's First Hurricane in Modern Times: Observations, Impacts, and Lessons Learned. Bull Am Meteorol Soc 98:26032618. https://doi.org/10.1175/BAMS-D-16-0222.1

3. Engel T, Fink AH, Knippertz P et al (2017) Extreme precipitation in the West African cities of Dakar and Ouagadougou: atmospheric dynamics and implications for flood risk assessments. J Hydrometeorol 18:2937-2957. https://doi.org/10.1175/ JHM-D-16-0218.1

4. Lafore J-P, Beucher F, Peyrillé P et al (2017) A multi-scale analysis of the extreme rain event of Ouagadougou in 2009. Q J R Meteorol Soc 143:3094-3109. https://doi.org/10.1002/qj.3165

5. Sall SM, Sauvageot H (2005) Cyclogenesis off the African Coast: The Case of Cindy in August 1999. Mon Weather Rev 133:28032813. https://doi.org/10.1175/MWR3003.1

6. Diaw, A.T. (1984) Morphométrie du littoral sénégalais et gambien. Notes Afr. 58-63, 6-21, 43

7. Ndoye S (2016) Fonctionnement dynamique du centre d'upwelling sud-sénégalais : approche par la modélisation réaliste et l'analyse d'observations satellite de température de la mer. PhD Thesis, Université Pierre et Marie Curie

8. Ndoye S, Capet X, Estrade P et al (2014) SST patterns and dynamics of the southern Senegal-Gambia upwelling center. J Geophys Res 119:8315-8335

9. Ndoye S, Capet X, Estrade P, et al (2017) Dynamics of a "lowenrichment high-retention" upwelling center over the southern Senegal shelf. Geophys Res Lett. https://doi.org/10.1002/2017G L072789

10. Roy C (1989) Fluctuation of wind and upwelling variability off the Senegalese coast. Ocean Acta 12:361-369

11. Capet X, Estrade P, Machu E et al (2017) On the dynamics of the southern Senegal upwelling center: observed variability from synoptic to super-inertial scales. J Phys Oceanogr 47:155-180. https://doi.org/10.1175/JPO-D-15-0247.1

12. Arnault J, Roux F (2011) Characteristics of African easterly waves associated with tropical cyclogenesis in the Cape Verde Islands region in July-August-September of 2004-2008. Atmos Res 100:61-82. https://doi.org/10.1016/j.atmosres.2010.12.028

13. Dieng AL, Eymard L, Sall SM et al (2014) Analysis of strengthening and dissipating mesoscale convective systems propagating 
off the West African coast. Mon Weather Rev 142:4600-4623. https://doi.org/10.1175/MWR-D-13-00388.1

14. Ndeye Astou Niang (2009) Dynamique socio-environnementale et développement local des régions côtières du Sénégal : l'exemple de la pêche artisanale. University of Rouen, Thesis

15. Landsea CW, Franklin JL (2013) Atlantic hurricane database uncertainty and presentation of a new database format. Mon Weather Rev 141:3576-3592. https://doi.org/10.1175/ MWR-D-12-00254.1

16. Cersat (2020) Daily Advanced Scatterometer (ASCAT) Surface wind fields level 3. http://apdrc.soest.hawaii.edu/datadoc/ascat. php. Accessed 02 Sept 2020

17. Bentamy A, Fillon DC (2012) Gridded surface wind fields from Metop/ASCAT measurements. Int J Remote Sens 33:1729-1754. https://doi.org/10.1080/01431161.2011.600348

18. Dee DP, Uppala SM, Simmons AJ et al (2011) The ERA-Interim reanalysis: configuration and performance of the data assimilation system. Q J R Meteorol Soc 137:553-597. https://doi.org/10. 1002/qj.828

19. Reynolds RW, Smith TM, Liu C et al (2007) Daily high-resolutionblended analyses for sea surface temperature. J Clim 20:54735496. https://doi.org/10.1175/2007JCLI1824.1

20. Shen J, Gong W (2009) Influence of model domain size, wind directions and Ekman transport on storm surge development inside the Chesapeake Bay: A case study of extratropical cyclone Ernesto, 2006. J Mar Syst 75(1-2):198-215

21. Janowitz GS, Pietrafesa $L$ (1996) Subtidal frequency fluctuations in coastal sea level in the Mid and South Atlantic Bights: a prognostic for coastal flooding. J Coast Res 12(1):79-88
22. Michaud $H$, Leredde $Y$, Estournel $C$, Berthebaud É, Marsaleix $P$ (2013) Modelling and in-situ measurements of intense currents during a winter storm in the Gulf of Aigues-Mortes (NW Mediterranean Sea). Comptes Rendus Geosci 345(9-10):361-372

23. Wang D-P, Elliott AJ (1978) Non-tidal variability in the Chesapeake Bay and Potomac River: evidence for non-local forcing. J Phys Oceanogr 8:225-232

24. Skamarock C, Klemp B, Dudhia J, et al (2008) A description of the advanced research WRF Version 3. https://doi.org/10.5065/ D68S4MVH

25. Kain JS (2004) The Kain-Fritsch convective parameterization: an update. J Appl Meteorol 43(1):170-181

26. Thompson G, Field PR, Rasmussen RM, Hall WD (2008) Explicit forecasts of winter precipitation using an improved bulk microphysics scheme. Part II: implementation of a new snow parameterization . Mon Weather Rev 136(12):5095-5115

27. Kelvin R (2014) Commentary: On the geological hazards that threaten existing and proposed reclamations of Manila Bay. Philip Sci Lett 7(1):1

28. Bell RJ, Gray SL, Jones OP (2017) North Atlantic storm driving of extreme wave heights in the North Sea. J Geophys Res Oceans 122:3253-3268. https://doi.org/10.1002/2016JC012501

Publisher's Note Springer Nature remains neutral with regard to jurisdictional claims in published maps and institutional affiliations. 